\title{
Biosorption of Crude Oil Spill Using Groundnut Husks and Plantain Peels as Adsorbents
}

\author{
Kenneth Kekpugile Dagde \\ Department of Chemical/Petrochemical Engineering, Rivers State University, Port Harcourt, Nigeria \\ Email: dagde.kenneth@ust.edu.ng
}

How to cite this paper: Dagde, K.K. (2018) Biosorption of Crude Oil Spill Using Groundnut Husks and Plantain Peels as Adsorbents. Advances in Chemical Engineering and Science, 8, 161-175. https://doi.org/10.4236/aces.2018.83011

Received: April 18, 2018

Accepted: July 22, 2018

Published: July 25, 2018

Copyright $\odot 2018$ by author and Scientific Research Publishing Inc. This work is licensed under the Creative Commons Attribution International License (CC BY 4.0).

http://creativecommons.org/licenses/by/4.0/

(c) (i) Open Access

\begin{abstract}
Adsorption techniques using meshed groundnut husks and plantain peels have provided cheap alternative to the conventional methods of crude oil spillage control and also for good waste management approach. The biodegradable nature of these adsorbents makes it a better alternative to the non biodegradable synthetic polymers. Dry unripe plantain peels and groundnut husks were used to prepare the adsorbents. The adsorption and percentage removal of crude oil from effluent produce water was dependent on adsorbent dosage, contact time, temperature and particle size. The particle size of the adsorbents should not be less than $150 \mu \mathrm{m}$ to avoid making the particles so loosed thus posing difficulty in recovery. The two adsorbents exhibit high affinity for oil adsorption with time especially at $75 \mu \mathrm{m}$, groundnut husk has a better performance because of its larger surface area and the presence of residual oil in the plantain peels. Agitation at $150 \mathrm{r} \cdot \mathrm{min}^{-1}$ and contact time between 15 - $75 \mathrm{~min}$ are recommended. The optimum adsorption temperature ranged between $25^{\circ} \mathrm{C}-45^{\circ} \mathrm{C}$ and $15^{\circ} \mathrm{C}-45^{\circ} \mathrm{C}$ for groundnut husks and plantain peels respectively. The adsorption data indicated that a pseudo-secondorder equation could be used to study the adsorption kinetics of both adsorbents.
\end{abstract}

\section{Keywords}

Biosorption, Bio-Adsorbents, Groundnut Husks, Plantain Peels, Kinetics

\section{Introduction}

The release of liquid petroleum hydrocarbon into the environment especially marine areas due to human activity is a form of pollution. There are existing methods for remediation but their limitations and impact to the environment have called for a more environmentally friendly spill control, some of the me- 
thods used are: in-situ burning of oil slick [1], mechanical techniques [2] [3] [4], bioremediation [5] [6], dispersants [7] [8] [9], sorbents of which is divided into the inorganic materials [9] [10], synthetic organic materials [11] [12] and the natural materials. Of the above listed remediation measures, sorbents such as agricultural products (i.e. the natural materials) have been found to possess high sorption capacity and are environmentally friendly. Therefore, an extensive body of researchers have published the efficacy of numerous agricultural products for oil cleanup processes some of which are meshed groundnut husk [13], meshed groundnut shell activated carbon [14], jatropha curcas fruit pericarp and seed coat [15], plantain pseudo stem [16], sugarcane [17]; cotton grass fiber [18]; corn cobs [19]; coconut shell [20]. The works of Uzoije et al. (2011) [14], Nwokoma et al. [13] (2010) and Okoromah et al. [16] (2013) have showed that crude oil could be successively removed from a contaminated water using activated meshed groundnut husks, ordinary meshed groundnut husks, and plantain pseudo stem respectively but plantain peels and a comparative kinetic and mechanism study of the meshed groundnut husks and plantain peels adsorbents in removing crude oil spill will be investigated in this work. The effect of adsorbents mass and particle size; feed (adsorbate) concentration, residence/contact time and temperature on adsorption will be determined. It will compare the most effective of the two adsorbents used and examine the loading, adsorption capacity and the adsorption kinetics.

\section{Materials and Methods}

\subsection{Apparatus and Reagents}

Meshing machine (Magimix Cuisine System 5000), Mesh sieve (B.S.410/43), Hygrometer (Fisher Scientific Company), Orbital shaker bath (HY-2 model NYC), Distillation Apparatus (ASTM D4006-11), Thermometer, Graduated bottles and beakers (Pyrex, England), Weighing balance (AL meter Toledo Gmbh 2004) and boat, $0.45 \mu \mathrm{m}$ micro-porous membrane filter (ASTME-11 spec, Fisher Scientific Co), Separation funnel (Pyrex, England), Oven (Gallenkamp, England), Groundnut husks, Crude Oil (Bonny export blend, xylene), De-ionized water.

\subsection{Experimental Procedures}

The groundnut husks and plantain peels were sourced from a local groundnut oil processing plant and plantain chips industry in Port Harcourt, Rivers State, Nigeria. The samples were thoroughly washed with de-ionized water to remove any occluded impurities and dried in an oven to remove any moisture in order to stabilize the weights. After which; they were meshed and sieved into different particle sizes for use in several Batch adsorption experiments. The effluent produced water was taken from the Nigeria Agip Oil Company Limited (NAOC) facility. The crude oil contents in the produced water was determined using the American Society for Testing and Materials (ASTM D3921-73). Produced water 
containing $12.0 \mathrm{~g}$ of the crude oil having a volume of 1litre of which $75 \mathrm{ml}$ (containing $0.9443 \mathrm{~g}$ of crude) was withdrawn for each experiment. The effluent water was put in a 1 liter beaker, a specified amount of $150 \mu \mathrm{m}$ groundnut husks adsorbent was then added to the mixture. The beaker containing the mixture was placed on an orbital shaker at $150 \mathrm{r} \cdot \mathrm{min}^{-1}$ at a specified temperature for 45 min. The wetted adsorbent was then removed from the beaker; oil and water was filtered through a $0.45 \mu \mathrm{m}$ micro porous membrane filter and weighed. The water content in the adsorbent was measured using the Dean and stack distillation technique described in ASTM D4006-11. The wetted adsorbent to the oil/water was refluxed with xylene. Organic solvent and water was continuously condensed into a trap. The water settled in the graduated section of the trap and the solvent returned to the still. This procedure was repeated using plantain peels adsorbent under the same operating conditions. For each experiment the above procedures were followed under the specified operating conditions.

\subsection{Effect of Adsorbent Dosage}

Batch adsorption experiments were carried out using the two adsorbents with the following dosages: $10.0 \mathrm{~g} ; 15.0 \mathrm{~g} ; 20.0 \mathrm{~g} ; 25.0 \mathrm{~g}$ and $30.0 \mathrm{~g}$ at $25^{\circ} \mathrm{C}$. The weight of oil adsorbed was recorded as $\mathrm{g} \cdot \mathrm{g}^{-1}$ of sorbent.

\subsection{Effect of Contact Time}

The adsorption dynamics in terms of contact time was investigated using $15.0 \mathrm{~g}$ of $150 \mu \mathrm{m}$ adsorbent and then shaken at $150 \mathrm{r} \cdot \mathrm{min}^{-1}$ at $25^{\circ} \mathrm{C}$ and at $60^{\circ} \mathrm{C}$ for a $15,30,45,60$ and 75 minutes. The weights of oil adsorbed at the specified time intervals were determined by subtracting the water content and the initial adsorbent weight from the total wetted sorbent and was recorded as $\mathrm{g} \cdot \mathrm{g}^{-1}$ of sorbent.

\subsection{Effect of Temperature}

Batch adsorption experiment was carried out at $15^{\circ} \mathrm{C}, 25^{\circ} \mathrm{C}, 35^{\circ} \mathrm{C}, 45^{\circ} \mathrm{C}, 55^{\circ} \mathrm{C}$ and $60^{\circ} \mathrm{C}$ for $15.0 \mathrm{~g}$ of the meshed adsorbents which were shaken at $150 \mathrm{r} \cdot \mathrm{min}^{-1}$ for $60 \mathrm{~min}$. The weights of oil adsorbed using the adsorbents at specified temperatures were determined by subtracting the water content and the initial adsorbent weight from the total wetted sorbent and were recorded as $\mathrm{g} \cdot \mathrm{g}^{-1}$ of sorbents.

\subsection{Effect of Particle Sizes}

The adsorbents were meshed and sieved into different particle sizes: 75, 150, 212, 400 and $500 \mu \mathrm{m}$. Batch adsorption experiments was carried out for the various sizes of the adsorbents by using $15.0 \mathrm{~g}$ of the meshed adsorbents. The weights of oil adsorbed at various particle sizes were determined by subtracting the water content and the initial adsorbent weight from the total wetted sorbent and was recorded as g.g $\mathrm{g}^{-1}$ of sorbent. 


\subsection{Estimation of Adsorption Kinetics}

Adsorption kinetics of crude oil in produced water onto groundnut husks and plantain peels were determined from the data obtained from those experiments using Equations (1)-(4):

The amount of oil adsorbed in $\mathrm{g} \cdot \mathrm{g}^{-1}$ from $t=0$ to $t=t$ will be:

$$
Q_{t}=\frac{G_{s}-\left(W_{\mathrm{H}_{2} \mathrm{O}}+G_{o}\right)}{G_{o}}
$$

where; $Q_{t}$ is the amount of oil adsorbed (Adsorption capacity) at time $\mathrm{t}$ in $\left(\mathrm{g} \cdot \mathrm{g}^{-1}\right)$, $G_{s}$ is the mass of wetted Adsorbents (g), $G_{o}$ is the initial Mass of adsorbent (g) and $W_{\mathrm{H}_{2} \mathrm{O}}$ is the Mass of water adsorbed (g).

The percentage removal of crude oil in solution will be:

$$
\% \text { Removal }=\frac{W_{s}}{W_{o}} \times 100
$$

where, $W_{s}$ is the Mass of oil adsorbed $(\mathrm{g}), W_{o}$ is the Initial Mass of Crude oil (g).

The kinetics of the crude oil adsorption onto meshed adsorbents was analyzed using the pseudo-second order kinetic model developed by Ho and Mckary [21] and expressed as:

$$
\frac{\mathrm{d} q}{\mathrm{~d} t}=-k_{2}\left(q_{e}-q\right)^{2}
$$

where, $k_{2}$ is the pseudo-second order kinetic rate constant.

Integrating under the boundary condition of $t=0$ to $t=t$ and $q=0$ to $q=q$ gives:

$$
\frac{t}{q_{t}}=\frac{1}{q_{e}} t+\frac{1}{k_{2} q_{e}^{2}}
$$

A plot of $t / q_{t}$ against $t$ gives a linear relationship from which $q_{e}$ and $k_{2}$ were determined from the slope and intercept of the plot, respectively.

The initial adsorption rate, $h\left(\mathrm{~g} / \mathrm{g}_{\min }\right)$ at $t=0$ was defined as:-

$$
h=k_{2} q_{e}^{2}
$$

\section{Results and Discussion}

The results of the effect of adsorbents dosage from the experiments are given in Table 1(a) and Table 1(b) for groundnut husks and plantain peels adsorbent respectively. Tables 2 (a)-(d) gave the results of the effect of contact time on adsorption at temperatures of $25^{\circ} \mathrm{C}$ and $60^{\circ} \mathrm{C}$ for groundnut husks and plantain peels respectively. The kinetic parameters for the adsorbents are given in Table 3(a) and Table 3(b) respectively. Table 4(a) and Table 4(b) are the results of temperatures for groundnut husks and plantain peels respectively. Whereas Table 5(a) and Table 5(b) gave the results of the effect of particle sizes. 
Table 1. (a) Adsorption at different adsorbent masses of groundnut husks; (b) Adsorption at different adsorbent masses of plantain peels.

(a)

\begin{tabular}{ccccccc}
\hline $\begin{array}{c}\text { Initial } \\
\begin{array}{c}\text { Mass of } \\
\text { adsorbent } \\
\boldsymbol{G}_{\boldsymbol{o}}(\mathrm{g})\end{array}\end{array}$ & $\begin{array}{c}\text { Mass of } \\
\text { wetted } \\
\text { adsorbent } \\
\boldsymbol{G}_{\boldsymbol{s}}(\mathrm{g})\end{array}$ & $\begin{array}{c}\text { Mass of water } \\
\text { adsorbed }\end{array}$ & $\begin{array}{c}\boldsymbol{W}_{\mathrm{H}_{2} \mathrm{O}} \quad(\mathrm{g}) \\
\text { Mass } \\
\text { of oil } \\
\text { adsorbed } \\
\boldsymbol{W}_{\text {ads }}(\mathrm{g})\end{array}$ & $\begin{array}{c}\boldsymbol{Q}_{t} \\
\left(\mathrm{~g} \cdot \mathbf{g}^{-1}\right)\end{array}$ & $\begin{array}{c}\% \\
\text { Removal }\end{array}$ & $\begin{array}{c}\text { Adsorbed } \\
\text { oil-water } \\
\text { ratio }(-)\end{array}$ \\
\hline 10 & 13.6583 & 3.0 & 0.6583 & 0.066 & 69.7 & 0.22 \\
15 & 19.5893 & 3.9 & 0.6893 & 0.046 & 73 & 0.18 \\
20 & 25.8715 & 5.1 & 0.7715 & 0.039 & 81.7 & 0.15 \\
25 & 32.5583 & 6.7 & 0.8583 & 0.034 & 90.89 & 0.13 \\
30 & 38.0819 & 7.2 & 0.8819 & 0.029 & 93.4 & 0.12 \\
\hline
\end{tabular}

(b)

\begin{tabular}{ccccccc}
\hline $\begin{array}{c}\text { Initial } \\
\begin{array}{c}\text { Mass of } \\
\text { adsorbent } G_{o} \\
(\mathrm{~g})\end{array}\end{array}$ & $\begin{array}{c}\text { Mass of } \\
\text { wetted } \\
\text { adsorbent } \\
\boldsymbol{G}_{\boldsymbol{s}}(\mathrm{g})\end{array}$ & $\begin{array}{c}\text { Mass of } \\
\text { water } \\
\text { adsorbed }\end{array}$ & $\begin{array}{c}\text { Mass of oil } \\
\boldsymbol{W}_{\mathrm{H}_{2} \mathrm{O}}(\mathrm{g})\end{array}$ & $\begin{array}{c}\boldsymbol{Q}_{\boldsymbol{t}} \\
\boldsymbol{W}_{\mathrm{ads}}(\mathrm{g})\end{array}$ & $\begin{array}{c}\% \\
\left(\mathrm{~g} \cdot \mathrm{g}^{-1}\right)\end{array}$ & $\begin{array}{c}\text { Adsorbed } \\
\text { oil-water } \\
\text { ratio (-) }\end{array}$ \\
\hline 10 & 12.5053 & 3.0 & 0.5053 & 0.051 & 53.5 & 0.25 \\
15 & 18.0761 & 2.5 & 0.5761 & 0.038 & 61 & 0.23 \\
20 & 24.3253 & 3.6 & 0.7253 & 0.036 & 76.81 & 0.2 \\
25 & 29.9231 & 4.1 & 0.8231 & 0.033 & 87.2 & 0.2 \\
30 & 35.8462 & 5.0 & 0.8462 & 0.028 & 89.61 & 0.18 \\
\hline
\end{tabular}

Table 2. (a) Adsorption at different contact time at $25^{\circ} \mathrm{C}$ for groundnut husks; (b) Kinetic parameters for the adsorption of crude oil onto meshed plantain peel; (c) Adsorption at different contact time at $25^{\circ} \mathrm{C}$ for plantain peels; (d) Adsorption at different contact time at $60^{\circ} \mathrm{C}$ for plantain peels.

(a)

\begin{tabular}{|c|c|c|c|c|c|c|c|}
\hline $\begin{array}{l}\text { Time } \\
(\min )\end{array}$ & $\begin{array}{c}\text { Mass of } \\
\text { wetted } \\
\text { adsorbent } \\
\quad G_{s}(\mathrm{~g})\end{array}$ & $\begin{array}{c}\text { Mass of } \\
\text { water } \\
\text { adsorbed } \\
W_{\mathrm{H}_{2} \mathrm{O}} \quad(\mathrm{g})\end{array}$ & $\begin{array}{c}\text { Mass } \\
\text { of oil } \\
\text { adsorbed } \\
w_{a d s}(\mathrm{~g})\end{array}$ & $\begin{array}{c}Q_{t} \\
\left(\mathrm{~g} \cdot \mathrm{g}^{-1}\right)\end{array}$ & $\begin{array}{c}t / Q_{t} \\
\left(\min \cdot g \cdot g^{-1}\right)\end{array}$ & $\begin{array}{c}\% \\
\text { Removal }\end{array}$ & $\begin{array}{c}\text { Adsorbed } \\
\text { oil-water } \\
\text { ratio (-) }\end{array}$ \\
\hline 15 & 18.103 & 2.51 & 0.6275 & 0.042 & 357.14 & 66.45 & 0.25 \\
\hline 30 & 20.06 & 4.4 & 0.6601 & 0.044 & 681.82 & 69.9 & 0.15 \\
\hline 45 & 22.54 & 6.8 & 0.7454 & 0.051 & 882.35 & 78.9 & 0.11 \\
\hline 60 & 23.70 & 7.9 & 0.8042 & 0.054 & 1111.11 & 85.16 & 0.102 \\
\hline 75 & 23.73 & 7.9 & 0.8277 & 0.055 & 1363.64 & 87.65 & 0.105 \\
\hline
\end{tabular}

(b)

\begin{tabular}{|c|c|c|c|c|c|c|c|}
\hline $\begin{array}{l}\text { Time } \\
(\min )\end{array}$ & $\begin{array}{c}\text { Mass of } \\
\text { wetted } \\
\text { adsorbent } \\
G_{s}(\mathrm{~g})\end{array}$ & $\begin{array}{l}\text { Mass of } \\
\text { water } \\
\text { adsorbed } \\
W_{\mathrm{H}_{2} \mathrm{O}} \quad(\mathrm{g})\end{array}$ & $\begin{array}{c}\text { Mass } \\
\text { of oil } \\
\text { adsorbed } w_{a d s} \\
\text { (g) }\end{array}$ & $\begin{array}{c}Q_{t} \\
\left(\mathrm{~g} \cdot \mathrm{g}^{-1}\right)\end{array}$ & $\begin{array}{c}t / Q_{t} \\
\left(\min \cdot g \cdot g^{-1}\right)\end{array}$ & $\begin{array}{c}\% \\
\text { Removal }\end{array}$ & $\begin{array}{c}\text { Adsorbed } \\
\text { oil-water } \\
\text { ratio (-) }\end{array}$ \\
\hline 15 & 19.14 & 3.5 & 0.6380 & 0.043 & 348.84 & 67.56 & 0.18 \\
\hline 30 & 20.36 & 4.7 & 0.6619 & 0.044 & 681.82 & 70.09 & 0.14 \\
\hline 45 & 21.02 & 5.3 & 0.07156 & 0.048 & 937.5 & 75.78 & 0.135 \\
\hline 60 & 21.78 & 6.0 & 0.7815 & 0.52 & 1153.83 & 82.76 & 0.13 \\
\hline 75 & 22.01 & 6.2 & 0.8102 & 0.054 & 1388.89 & 85.81 & 0.13 \\
\hline
\end{tabular}


(c)

\begin{tabular}{cccccccc}
\hline $\begin{array}{c}\text { Time } \\
(\mathrm{min})\end{array}$ & $\begin{array}{c}\text { Mass of } \\
\text { wetted ad- } \\
\text { sorbent } G_{s} \\
(\mathrm{~g})\end{array}$ & $\begin{array}{c}\text { Mass } \\
\text { of water } \\
\text { adsorbed } \\
W_{\mathrm{H}_{2} \mathrm{O}}(\mathrm{g})\end{array}$ & $\begin{array}{c}\text { Mass } \\
\text { of oil } \\
\text { adsorbed } \\
\boldsymbol{W}_{\text {ads }}(\mathrm{g})\end{array}$ & $\begin{array}{c}\boldsymbol{Q}_{t} \\
\left(\mathrm{~g} \cdot \mathrm{g}^{-1}\right)\end{array}$ & $\begin{array}{c}t / Q_{t} \\
\left(\mathrm{~min} \cdot \mathrm{g} \cdot \mathrm{g}^{-1}\right)\end{array}$ & $\begin{array}{c}\% \\
\text { Removal }\end{array}$ & $\begin{array}{c}\text { Adsorbed } \\
\text { oil-water } \\
\text { ratio (-) }\end{array}$ \\
\hline 15 & 17.51 & 1.92 & 0.5768 & 0.031 & 483.87 & 61.08 & 0.3 \\
30 & 19.19 & 3.36 & 0.6393 & 0.036 & 883.33 & 60.7 & 0.19 \\
45 & 20.21 & 4.5 & 0.7146 & 0.044 & 1022.73 & 75.68 & 0.16 \\
60 & 20.83 & 5.07 & 0.7607 & 0.048 & 1250 & 80.6 & 0.15 \\
75 & 21.16 & 5.36 & 0.8041 & 0.051 & 1470.59 & 85.15 & 0.15 \\
\hline
\end{tabular}

(d)

\begin{tabular}{cccccccc}
\hline $\begin{array}{c}\text { Time } \\
(\mathrm{min})\end{array}$ & $\begin{array}{c}\text { Mass of } \\
\text { wetted } \\
\text { adsorbent } \\
G_{s}(\mathrm{~g})\end{array}$ & $\begin{array}{c}\text { Mass } \\
\text { of water } \\
\text { adsorbed } \\
W_{\mathrm{H}_{2} \mathrm{O}} \quad(\mathrm{g})\end{array}$ & $\begin{array}{c}\text { Mass } \\
\text { of oil } \\
\text { adsorbed } \\
\boldsymbol{W}_{\text {ads }}(\mathrm{g})\end{array}$ & $\begin{array}{c}Q_{t} \\
\left(\mathrm{~g} \cdot \mathrm{g}^{-1}\right)\end{array}$ & $\begin{array}{c}t / Q_{t} \\
\left(\mathrm{~min} \cdot \mathbf{g}^{-1}\right)\end{array}$ & $\begin{array}{c}\% \\
\text { Removal }\end{array}$ & $\begin{array}{c}\text { Adsorbed } \\
\text { oil-water } \\
\text { ratio }(-)\end{array}$ \\
\hline 15 & 18.085 & 2.5 & 0.5850 & 0.039 & 384.615 & 63.07 & 0.23 \\
30 & 18.92 & 3.3 & 0.6204 & 0.041 & 731.71 & 65.7 & 0.19 \\
45 & 20.106 & 4.4 & 0.7057 & 0.047 & 957.45 & 74.73 & 0.16 \\
60 & 20.58 & 4.8 & 0.7825 & 0.052 & 1153.85 & 82.87 & 0.162 \\
75 & 21.0 & 5.16 & 0.08457 & 0.056 & 1339.286 & 89.56 & 0.164 \\
\hline
\end{tabular}

Table 3. (a) Kinetic parameters for the adsorption of crude oil onto meshed groundnut husks; (b) Kinetic parameters for the adsorption of crude oil onto meshed plantain peels.

(a)

\begin{tabular}{ccccc}
\hline Temperature $\left({ }^{\circ} \mathrm{C}\right)$ & $\begin{array}{c}K \\
\left(\mathrm{~g} \cdot \mathrm{g}^{-1} \mathrm{~min}\right)\end{array}$ & $\begin{array}{c}Q_{e} \\
\left(\mathrm{~g} \cdot \mathrm{g}^{-1}\right)\end{array}$ & $\begin{array}{c}\boldsymbol{h} \\
\left(\mathrm{g} \cdot \mathrm{g}^{-1} \cdot \mathrm{min}\right)\end{array}$ & $\boldsymbol{R}^{2}$ \\
\hline 25 & 1.809257 & 0.061418 & 0.006825 & 0.9942 \\
60 & 2.120118 & 0.058774 & 0.007324 & 0.9926 \\
\hline
\end{tabular}

(b)

\begin{tabular}{ccccc}
\hline Temperature $\left({ }^{\circ} \mathrm{C}\right)$ & $\begin{array}{c}K \\
\left(\mathrm{~g} \cdot \mathrm{g}^{-1} \mathrm{~min}\right)\end{array}$ & $\begin{array}{c}Q_{e} \\
\left(\mathrm{~g} \cdot \mathrm{g}^{-1}\right)\end{array}$ & $\begin{array}{c}\boldsymbol{h} \\
\left(\mathrm{g} \cdot \mathrm{g}^{-1} \cdot \mathrm{min}\right)\end{array}$ & $R^{2}$ \\
\hline 25 & 0.760403 & 0.0641 & 0.003124 & 0.9743 \\
60 & 1.129261 & 0.064337 & 0.004674 & 0.9816 \\
\hline
\end{tabular}

Table 4. (a) Adsorption at different temperatures for groundnut husks; (b) Adsorption at different temperature for plantain peels.

(a)

\begin{tabular}{ccccccc}
\hline $\begin{array}{c}\text { Temperature } \\
\left({ }^{\circ} \mathrm{C}\right)\end{array}$ & $\begin{array}{c}\text { Mass of } \\
\text { wetted } \\
\text { adsorbent } \\
\boldsymbol{G}_{\boldsymbol{s}}(\mathrm{g})\end{array}$ & $\begin{array}{c}\text { Mass of } \\
\text { water } \\
\text { adsorbed } \\
\boldsymbol{W}_{\mathrm{H}_{2} \mathrm{O}} \quad(\mathbf{g})\end{array}$ & $\begin{array}{c}\text { Mass of } \\
\text { oil adsorbed } \\
W_{\text {ads }}(\mathrm{g})\end{array}$ & $\begin{array}{c}\boldsymbol{Q}_{t} \\
\mathbf{g} \cdot \mathbf{g}^{-1}\end{array}$ & $\begin{array}{c}\% \\
\text { Removal }\end{array}$ & $\begin{array}{c}\text { Adsorbed } \\
\text { oil water } \\
\text { ratio (-) }\end{array}$ \\
\hline 15 & 19.49 & 3.9 & 0.5871 & 0.039 & 62.170 & 0.15 \\
25 & 19.71 & 4 & 0.7125 & 0.048 & 75.45 & 0.178 \\
35 & 19.94 & 4.19 & 0.7506 & 0.05 & 79.49 & 0.179 \\
45 & 20.12 & 4.34 & 0.7814 & 0.052 & 82.75 & 0.18 \\
60 & 20.30 & 4.49 & 0.8128 & 0.054 & 86.07 & 0.181 \\
\hline
\end{tabular}


(b)

\begin{tabular}{ccccccc}
\hline $\begin{array}{c}\text { Temperature } \\
\left({ }^{\circ} \mathrm{C}\right)\end{array}$ & $\begin{array}{c}\text { Mass } \\
\text { of wetted } \\
\text { adsorbent } \\
G_{s}(\mathrm{~g})\end{array}$ & $\begin{array}{c}\text { Mass } \\
\text { of water } \\
\text { adsorbed } \\
W_{\mathrm{H}_{2} \mathrm{O}}(\mathrm{g})\end{array}$ & $\begin{array}{c}\text { Mass } \\
\text { of oil } \\
\text { adsorbed } \\
W_{\text {ads }}(\mathrm{g})\end{array}$ & $\begin{array}{c}Q_{t} \\
\mathbf{g}^{-\mathbf{g}^{-1}}\end{array}$ & $\begin{array}{c}\% \\
\text { Removal }\end{array}$ & $\begin{array}{c}\text { Adsorbed } \\
\text { oil water } \\
\text { ratio }(-)\end{array}$ \\
\hline 15 & 17.81 & 2.32 & 0.4871 & 0.032 & 51.58 & 0.21 \\
25 & 18.11 & 2.48 & 0.6198 & 0.039 & 65.64 & 0.25 \\
35 & 18.25 & 2.58 & 0.6712 & 0.045 & 71.08 & 0.26 \\
45 & 18.97 & 2.61 & 0.6881 & 0.045 & 72.87 & 0.265 \\
60 & 18.99 & 2.67 & 0.7201 & 0.040 & 76.26 & 0.27 \\
\hline
\end{tabular}

Table 5. (a) Adsorption at different particle sizes for groundnut husks; (b) Adsorption at different particle sizes for plantain peels.

(a)

\begin{tabular}{|c|c|c|c|c|c|c|}
\hline $\begin{array}{c}\text { Particle } \\
\text { size }(\mu \mathrm{m})\end{array}$ & $\begin{array}{c}\text { Mass of } \\
\text { wetted } \\
\text { adsorbent } \\
G_{s}(\mathrm{~g})\end{array}$ & $\begin{array}{c}\text { Mass of } \\
\text { water } \\
\text { adsorbed } \\
W_{\mathrm{H}_{2} \mathrm{O}} \quad(\mathrm{g})\end{array}$ & $\begin{array}{c}\text { Mass of } \\
\text { oil adsorbed } \\
W_{a d s}(\mathrm{~g})\end{array}$ & $\begin{array}{c}Q_{t} \\
\mathrm{~g} \cdot \mathrm{g}^{-1}\end{array}$ & $\begin{array}{c}\% \\
\text { Removal }\end{array}$ & $\begin{array}{l}\text { Adsorbed } \\
\text { oil water } \\
\text { ratio (-) }\end{array}$ \\
\hline 75 & 20.693 & 4.8 & 0.8930 & 0.0595 & 94.57 & 0,106 \\
\hline 150 & 20.912 & 5.14 & 0.7718 & 0.0514 & 81.73 & 0.15 \\
\hline 212 & 20.6501 & 5 & 0.6501 & 0.043 & 68.84 & 0.13 \\
\hline 400 & 21.2861 & 5.72 & 0.5661 & 0.038 & 59.95 & 0.099 \\
\hline 500 & 21.425 & 5.9 & 0.5251 & 0.035 & 55.61 & 0.089 \\
\hline
\end{tabular}

(b)

\begin{tabular}{ccccccc}
\hline $\begin{array}{c}\text { Mass of } \\
\text { wetted } \\
(\mu \mathrm{m})\end{array}$ & $\begin{array}{c}\text { Mass of } \\
\text { water } \\
\text { adsorbent } \\
\boldsymbol{G}_{\boldsymbol{s}}(\mathrm{g})\end{array}$ & $\begin{array}{c}\text { Mass } \\
\text { adsorbed } \\
\boldsymbol{W}_{\mathrm{H}_{2} \mathrm{O}}(\mathrm{g})\end{array}$ & $\begin{array}{c}\text { of oil } \\
\text { adsorbed } \\
(\mathrm{g})\end{array}$ & $\begin{array}{c}Q_{t} \\
\mathbf{g} \cdot \mathbf{g}^{-1}\end{array}$ & $\begin{array}{c}\text { \% } \\
\text { Removal }\end{array}$ & $\begin{array}{c}\text { Adsorbed } \\
\text { oil water } \\
\text { ratio }(-)\end{array}$ \\
\hline 75 & 20.155 & 4.31 & 0.8450 & 0.056 & 89.48 & 0.196 \\
150 & 20.195 & 4.49 & 0.7057 & 0.047 & 74.67 & 0.157 \\
212 & 20.129 & 4.515 & 0.6141 & 0.041 & 65.03 & 0.135 \\
400 & 21.235 & 5.71 & 0.5250 & 0.035 & 55.597 & 0.092 \\
500 & 21.41 & 5.93 & 0.04801 & 0.032 & 50.84 & 0.081 \\
\hline
\end{tabular}

\subsection{Effect of Doses}

The adsorption capacity (g/g), percentage oil removal and adsorbed oil-water ratio at different sorbent doses are shown in Figures 1(a)-(c) respectively.

The adsorption increased with increase in adsorbent dose as shown in Figure 1 (a). As the adsorbent dose increased from $10 \mathrm{~g}$ to $30 \mathrm{~g}$; adsorption capacity of groundnut husk reduces from 0.066 to $0.029 \mathrm{~g} \cdot \mathrm{g}^{-1}$ and that of plantain peels from 0.051 to $0.028 \mathrm{~g} \cdot \mathrm{g}^{-1}$. The decrease in adsorption capacity may be due to the fact that some adsorption sites may have remained unsaturated during the adsorption 


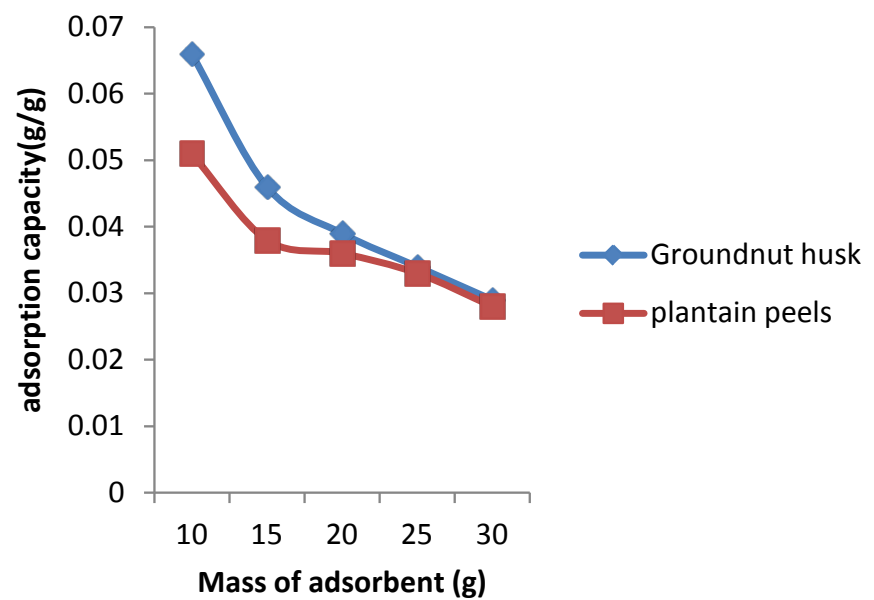

(a)
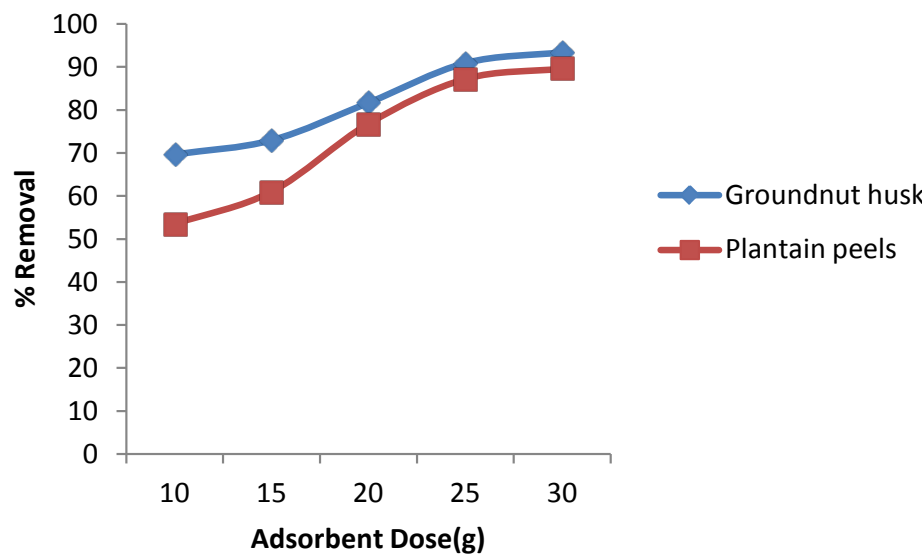

(b)

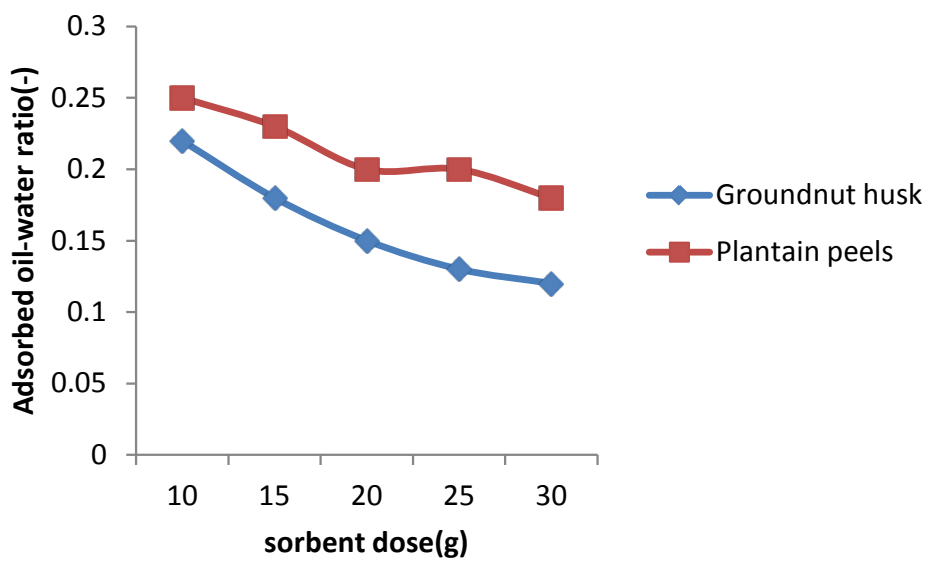

(c)

Figure 1. (a) Adsorption capacity at different sorbent Doses; (b) oil \% Removal at different sorbent Doses; (c) Adsorbed oil-water ratio at different sorbent doses.

process since more adsorption sites were available for the same concentration of sorbent (crude oil).The percentage removal of oil increased from $69.7 \%$ to $93.4 \%$ for groundnut husks and $53.5 \%$ to $89.61 \%$ for plantain peels as sorbent dose increased from $10 \mathrm{~g}$ to $30 \mathrm{~g}$ as shown in Figure $1(\mathrm{~b})$. This shows that by increasing 
the adsorbent dose the efficiency of the two adsorbents (groundnut husks and plantain peels) increased.

Figure 1(c) shows that adsorbed-oil water ratio decreased with increased in initial adsorbent mass. Both adsorbent showed similar characteristics but groundnut husk showed a higher performance compared to plantain peels.

\subsection{Effect of Contact Time}

The effect of contact time on adsorption for the two adsorbents at $25^{\circ} \mathrm{C}$ and $60^{\circ} \mathrm{C}$ are shown in Figures 2(a)-(f). The adsorption capacity of groundnut husk at $25^{\circ} \mathrm{C}$ increased from 0.042 to $0.055 \mathrm{~g} \cdot \mathrm{g}^{-1}$ and that of plantain peels from 0.031 to $0.051 \mathrm{~g} \cdot \mathrm{g}^{-1}$ whereas the percentage removal at $25^{\circ} \mathrm{C}$ for groundnut husks increased from $66.45 \%$ to $87.65 \%$ and for plantain peels from $61.08 \%$ to $85.15 \%$ as the time increase from 15 to $75 \mathrm{~min}$. While at $60^{\circ} \mathrm{C}$ with the same time increase, the adsorption capacity of groundnut husks increased from 0.043 to $0.054 \mathrm{~g}^{-\mathrm{g}^{-1}}$

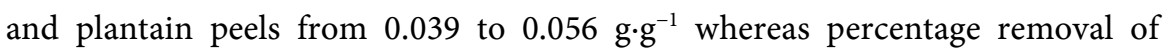
groundnut increased from $67.56 \%$ to $85.81 \%$ and that of plantain peels from $63.07 \%$ to $89.56 \%$.

The adsorbed oil-water ratio at different time interval at $25^{\circ} \mathrm{C}$ and $60^{\circ} \mathrm{C}$ for the two adsorbents decreased from 0.25 to 0.105 for groundnut husks and 0.3 to 0.15 for plantain peels at $25^{\circ} \mathrm{C}$ and from 0.18 to 0.13 for groundnut husks and 0.23 to 0.164 for plantain peels at $60^{\circ} \mathrm{C}$. An increase in adsorption capacity and percentage removal suggests that $150 \mathrm{r} \cdot \mathrm{min}^{-1}$ agitation speed was adequate to allow the binding sites adsorbed more crude oil as the contact time increased for the two adsorbents. Increased in adsorbed oil-water ratio implied that more water was adsorbed on exceeding the time equilibrium concentration of oil but groundnut husks absorbed more water than plantain peels.

Using the pseudo-second order equation to describe the type of adsorption as has been suggested as being more appropriate for this type of adsorption [22] (HO et al., 2002); the kinetic plots of $t / Q_{t}$ against $t$ for oil adsorption is presented in Figure 3. The linear relationship and the correlation coefficients as shown in Table 3(a) and Table 3(b) for the two adsorbents in the temperature range showed a strong relationship between the parameters and also explain that the adsorption process follows pseudo second-order kinetics and groundnut husks serving better than plantain peels as shown by the correlation factors. It shows that for groundnut husk though the amount of crude oil adsorbed at equilibrium $Q_{e}$ decreased from 0.061418 to $0.058774{\mathrm{~g} \cdot \mathrm{g}^{-1}}^{-1}$ as temperature increased from $25^{\circ} \mathrm{C}$ to $60^{\circ} \mathrm{C}$; the rate constant $K$ increased from 1.809257 to $2.120118 \mathrm{~g} \cdot \mathrm{g}^{-1} \cdot \mathrm{min}$; whereas the initial adsorption rate increased from 0.006825 to 0.007324 $\mathrm{g} \cdot \mathrm{g}^{-1} \cdot \mathrm{min}$. For that of plantain peels, the amount of crude oil adsorbed at equili-

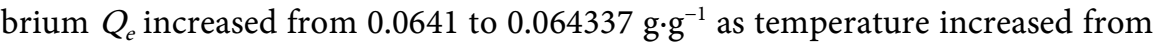
$25^{\circ} \mathrm{C}$ to $60^{\circ} \mathrm{C}$; the rate constant $K$ on the other hand increased from 0.760403 to $1.129261 \mathrm{~g} \cdot \mathrm{g}^{-1} \cdot \mathrm{min}$; whereas the initial adsorption rate increased from 0.003124 to $0.004674 \mathrm{~g} \cdot \mathrm{g}^{-1} \cdot \mathrm{min}$. 


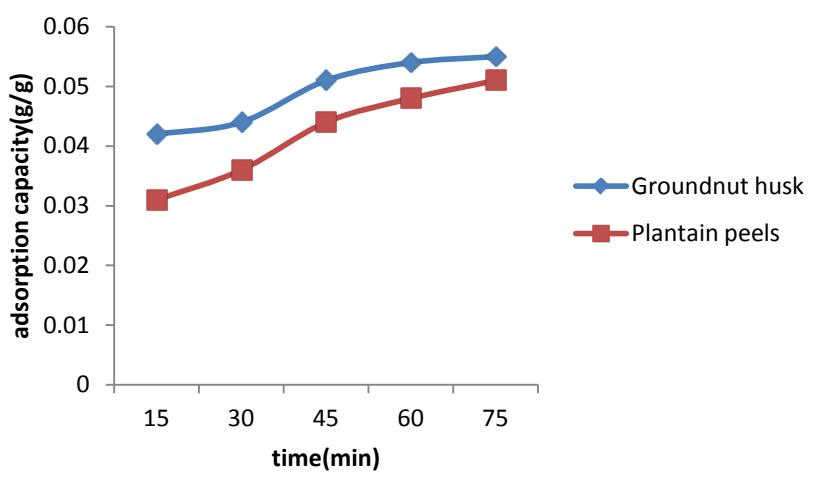

(a)

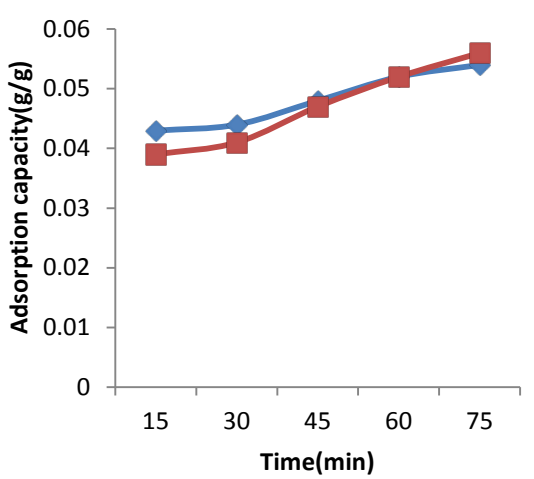

$\leadsto$ Groundnut husk

- -Plantain peels

(b)

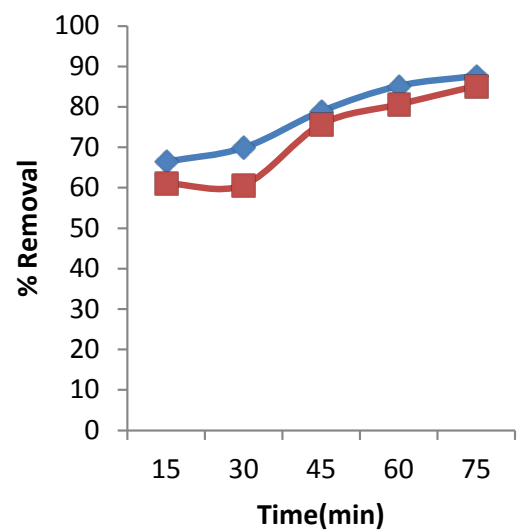

$\leadsto$ Groundnut husk

-Plantain peels

(c)

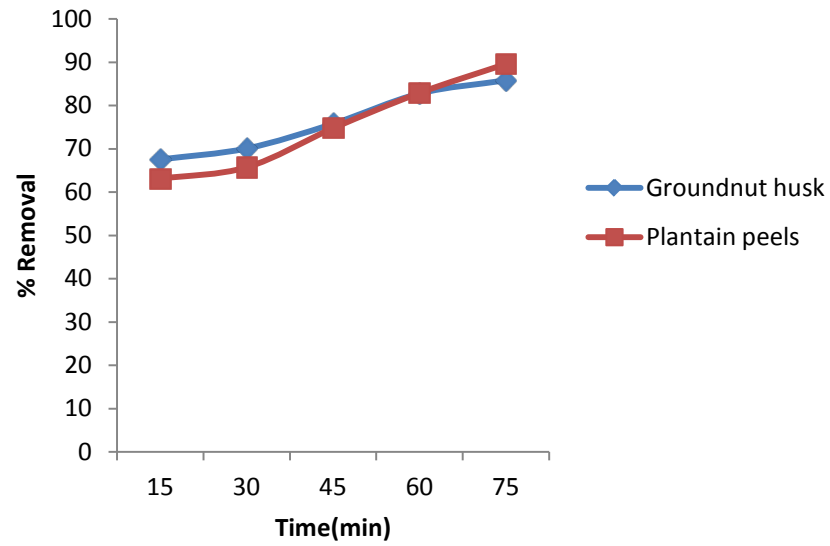

(d) 


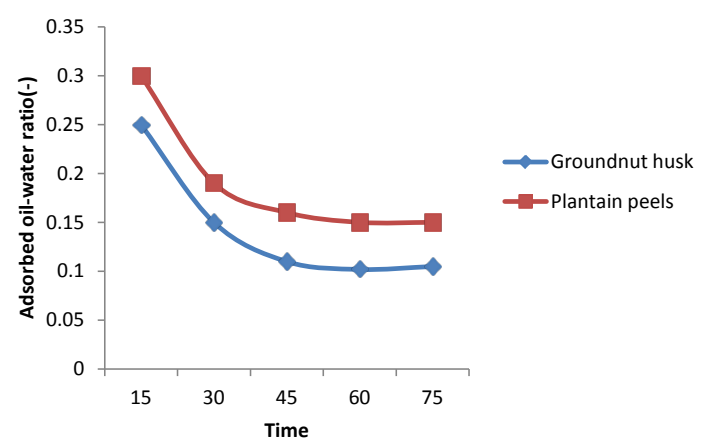

(e)

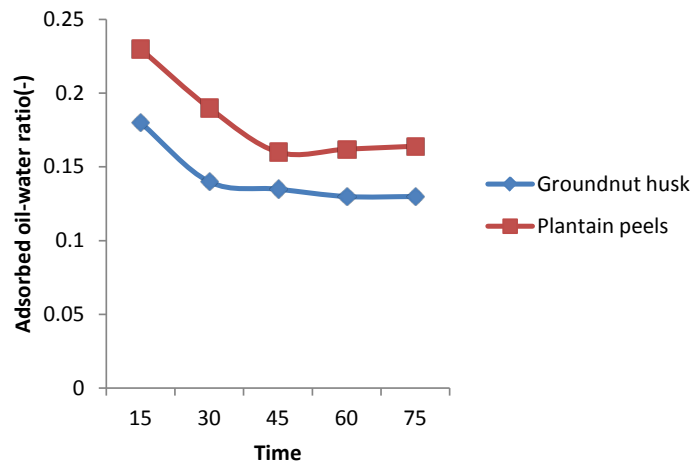

(f)

Figure 2. (a) Adsorption capacity at different Contact time at $25^{\circ} \mathrm{C}$; (b) Adsorption capacity at different contact time at $60^{\circ} \mathrm{C}$; (c) Percentage removal at different contact time at $25^{\circ} \mathrm{C}$; (d) Percentage removal at different contact time at $60^{\circ} \mathrm{C}$; (e) Adsorbed oil-water ratio at different contact time at $25^{\circ} \mathrm{C}$; (f) Adsorbed oil-water ratio at different contact time at $60^{\circ} \mathrm{C}$.

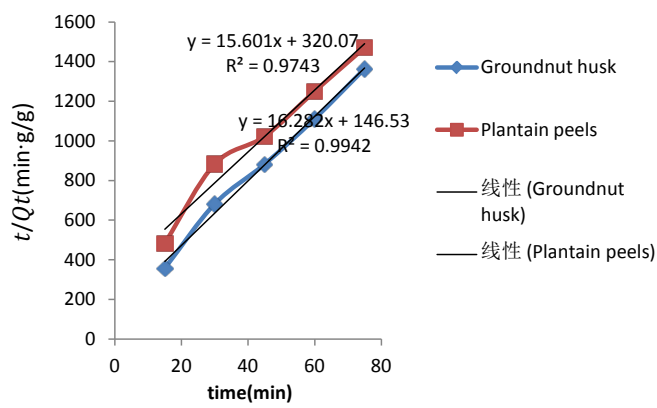

(a)

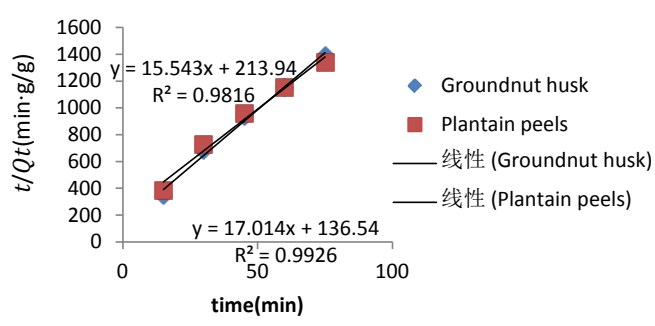

(b)

Figure 3. (a) Pseudo-second-order kinetic plot for the adsorption of crude oil onto groundnut husk and plantain peels at $25^{\circ} \mathrm{C}$; (b): pseudo-second-order kinetic plot for the adsorption of crude oil onto groundnut husk and plantain peels at $60^{\circ} \mathrm{C}$. 


\subsection{Effect of Temperature}

The result of batch adsorption experiment carried out for different temperatures of adsorbent is given in Table 4(a) and Table 4(b) for groundnut husks and plantain peels respectively. Figure 4(a) shows that adsorption capacity increased with temperature for groundnut husks; the optimum temperature range of the meshed groundnut husks to adsorb the effluent water sample containing $0.9443 \mathrm{~g}$

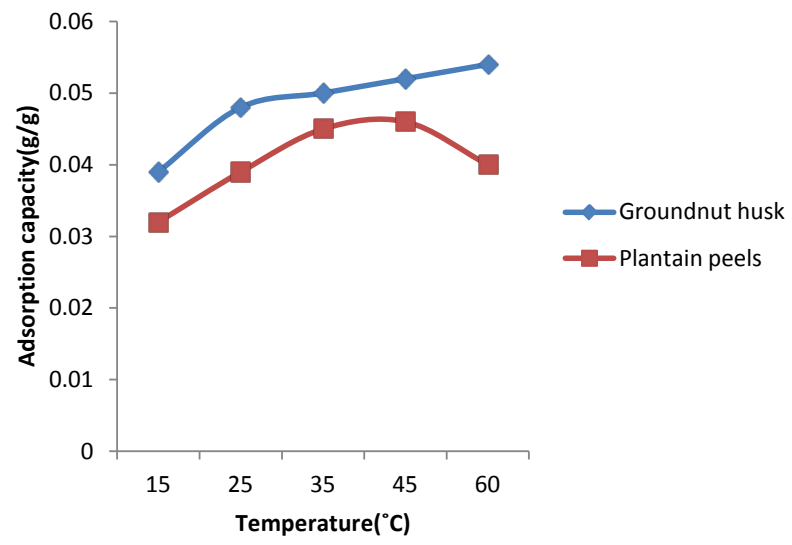

(a)

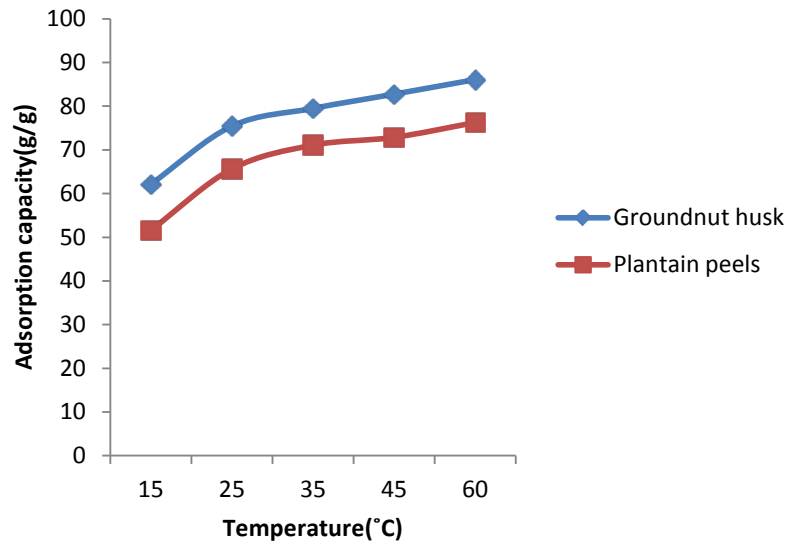

(b)

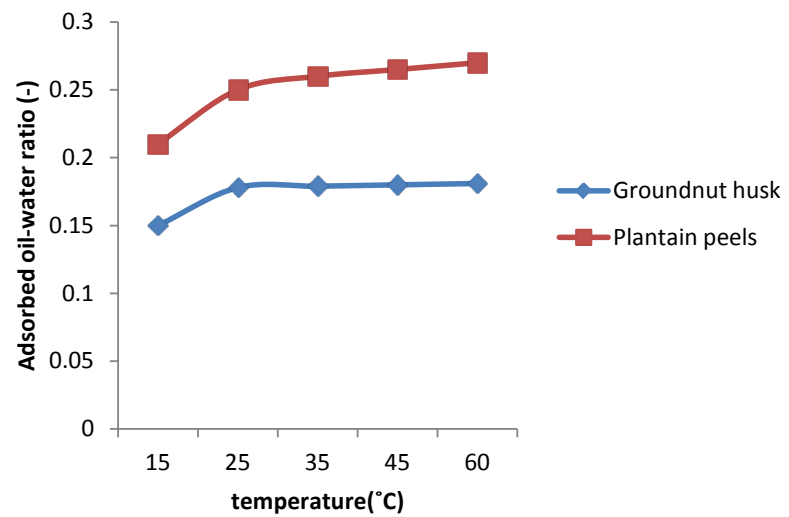

(c)

Figure 4. (a) Adsorption capacity at Different temperatures; (b) Percentage removal at different temperature; (c) Adsorbed oil-water ratio at different temperatures. 
of crude oil was $25^{\circ} \mathrm{C}-45^{\circ} \mathrm{C}$ indicating that the sorption process was an adsorption process and depended on the temperature whereas that of plantain peels showed an increase from $15^{\circ} \mathrm{C}-45^{\circ} \mathrm{C}$ and a sharp decrease; the optimum temperature was $45^{\circ} \mathrm{C}$. The sharp decrease shows a low adsorption interaction between the adsorbent and the adsorbate at increased temperature for plantain peels but a better interaction with groundnut husk.

Figure 4(b) and Figure 4(c) showed that the percentage removal of the crude oil as well as the adsorbed oil-water ratio increased with increase in temperature for both adsorbents.

\subsection{Effect of Particle Size}

The result of batch adsorption experiment carried out for different particle sizes of the adsorbents are given in Table 5(a) and Table 5(b) for plantain peels and groundnut husks respectively. Figures 5(a)-(c) show that smaller particles of

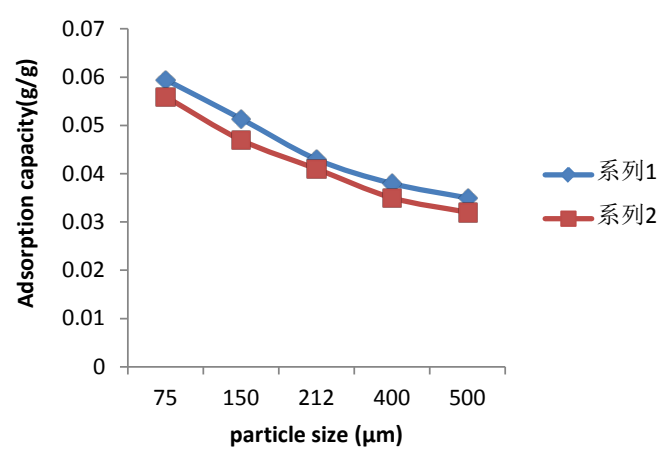

(a)

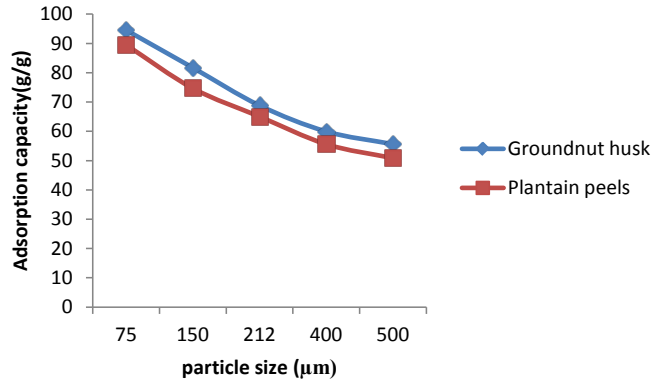

(b)

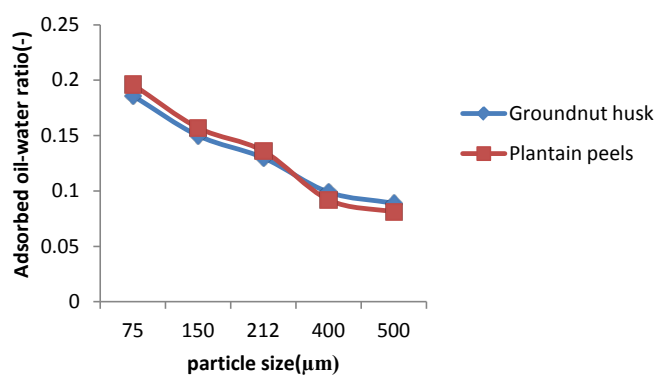

(c)

Figure 5. (a) Adsorption capacity at different Particle sizes; (b) Percentage removal at different particle sizes; (c) Adsorbed oil water ratio at different particle sizes. 
both adsorbents have relatively higher adsorption capacity percentage removal and adsorbed oil-water ratio respectively and the rate of adsorption increased with increase in surface area of the adsorbent while sorption efficiency increased with holding capacity. The differences in adsorption capacity, percentage removal of oil and adsorbed oil-water ratio between the different particle sizes of groundnut husks and plantain peels could be explained by the fact that smaller particles possessed not only larger surface areas and interstitial packing; but also the tendency of producing shorter time of equilibration.

\section{Conclusion}

The adsorption of crude oil using meshed groundnut husk and plantain peels as adsorbents have been studied. The results obtained showed that the percentage removal of crude oil from effluent produced water were dependent on adsorbent doses, contact time, temperature and particle size. The two adsorbents exhibited high affinity for oil adsorption especially at a particle size of $75 \mu \mathrm{m}$. Meshed groundnut husks had a better performance than plantain peels due to its larger surface areas and the presence of occluded residual oil retained in the meshed unripe plantain peels. The optimum adsorption temperature ranged for groundnut husks was $25^{\circ} \mathrm{C}-45^{\circ} \mathrm{C}$ and $15^{\circ} \mathrm{C}-45^{\circ} \mathrm{C}$ for plantain peels with a decrease at $60^{\circ} \mathrm{C}$. The adsorption data indicated that a pseudo-second-order equation could be used to study the adsorption kinetics of both adsorbents and the correlation coefficient indicated that the sorption process was dominated by adsorption process. As a result of the high affinity for oil and low water pick up; meshed groundnut husks and plantain peels adsorbent could be said to be oleophilic or hydrophobic. $150 \mathrm{r} \cdot \mathrm{min}^{-1}$ and contact time between 15 - 75 minutes is recommended for proper agitation so as to allow adsorption at the binding sites for the two adsorbents.

\section{References}

[1] Allen, A.A. (1988) In-Situ Burning, Alaska Arctic Offshore Oil Spill Response Technology. NIST Report No. SP 762, US Government Printing Office, Woodinville, 11-14.

[2] Muttin, F. (2008) Structural Analysis of Oil Spill Contaminant Booms in Coastal and Estuary Waters. Applied Ocean Research, 30, 107-112. https://doi.org/10.1016/j.apor.2008.07.001

[3] Castro, A., Iglesias, G., Arballa, R. and Fraguela, J.A. (2010) Floating Boom Performance under Waves and Currents. Journal by Hazardous Materials, 174, 226-235. https://doi.org/10.1016/j.jhazmat.2009.09.040

[4] Broje, V. and Keller, A.A. (2007) Effect of Operational Parameters on the Recovery Rate of an Oleophilic Drum Skimmer. Journal of Hazardous Materials, 148, 136-143. https://doi.org/10.1016/j.jhazmat.2007.02.017

[5] Smith, J.W. (1983) The Control of Oil Pollution. Graham and Trotman Limited, London, 157-171.

[6] Atlas, R.M. and Cerniglia, C.E. (1995) Bioremediation of Petroleum Pollutions. Bioscience, 45, 332-339. https://doi.org/10.2307/1312494 
[7] Daling P.S. and Indrebo, G. (1996) Recent Improvement in Optimizing Use of Dispersants as a Cost Effective Oil Spill Counter Measure Technique. Nigerian Society of Engineers, 1-15.

[8] Lewis, A., Inidel, B.K., Belore, R.C. and Mullin, J.V. (2010) Large Scale Dispersant Leaching and Effectiveness Experiments with Oils on Clam Water. Marine Pollution Bulletin, 60, 244-254. https://doi.org/10.1016/j.marpolbul.2009.09.019

[9] Mcleod, W.R. and Mcleod, D.L. (1974) Measures to Combat Arctic and Subarctic Oil Spill. Society of Petroleum Engineers, 1-10.

[10] Ladd, R.W. and Smith, D.D. (1970) System Study of Oil Spill Clean-Up Procedure. Society of Petroleum Engineers, 1-30.

[11] Sun, X.F., Sun, R. and Sun, J.X. (2002) Acetylation of Rice Straw with or without Catalysts and Its Characterization as a Natural Sorbent in Oil Spill Clean-Up. Journal of Agricultural and Food Chemistry, 50, 6428. https://doi.org/10.1021/jf0203920

[12] Deschamp, G., Carvel, H., Borredon, M.E., Bonnin, C. and Vignoles, C. (2003) Oil Removal from Water by Selective Sorption on Hydrophobic Cotton Fibres. Environmental Science and Technology, 37, 1013-1015. https://doi.org/10.1021/es020061s

[13] Nwokoma, D.B. and Anene, U. (2010) Adsorption of Crude Oil Using Meshed Groundnut Husk. Chemical Product and Process Modeling, 5, 1-20.

[14] Uzoije, A.P., Onunkwo, A. and Egwuonwu, N. (2011) Crude Oil Sorption onto Groundnut Shell Activated Carbon; Kinetic and Isotherm Studies. Research Journal of Environmental and Earth Sciences, 3, 555-563.

[15] Okeola, O.F., Odebunmi, E.O. and Ameen, O.M. (2012) Comparison of Sorption Capacity and Surface Area of Activated Carbon Prepared from Jatropha curcas Fruit Pericarp and Seed Coat. Bulletin of the Chemical Society of Ethiopia, 26, 171-180.

[16] Okoromah, C.O. and Ukpaka, C.P. (2013) Modeling the Biosorption of Crude Oil in Water Using Plantain Pseudo Stem as the Adsorbent. Journal of Engineering and Technology Research, 5, 122-138.

[17] Sun, X.F., Sun, R.C. and Sun, J.X. (2003) A Convenient Acetylation of Sugarcane Bagasse Using NBS ( $N$-Bromosuccinimide) as a Catalyst for Preparation of Oil Sorption-Active Material. Journal of Materials Science, 38, 3915-3923. https://doi.org/10.1023/A:1026189911651

[18] Suni, S., Kosunen, A.L., Hantala, M., Pasila, A. and Romantschuk, M. (2004) Use of a By-Product of Peat Excavation; Cotton Grass Fiber, as a Sorbent for Oil Spills. Marine Pollution Bulletin, 49, 916-921.

[19] Tsai, W.T., Chang, C.Y., Wang, S.Y., Chany, C.F., Chien, S.F. and Sun, H.F. (2001) Utilization of Agricultural Waste Corncob for the Preparation of Activated Carbon. Journal of Environmental Science and Health, 5B, 677-686. https://doi.org/10.1081/PFC-100106194

[20] Amuda, O.S. and Ibraham, A.O. (2006) Industrial Wastewater Treatment Using Natural Material as Adsorbent. African Journal of Biotechnology, 5, 1483-1487.

[21] Ho, Y.S. and Mckary, G. (1999) Pseudo-Second Order Model for Sorption Process. Process Biochemistry, 34, 451-465. https://doi.org/10.1016/S0032-9592(98)00112-5

[22] Ho, Y.S., Mckary, G., Wase, D. and Foster, C.F. (2002) Study of the Sorption of Divalent Metal Ion on to Peat. Adsorption Science \& Technology, 18, 639-650. 